\title{
Neutron Activation Analyses Used to Study Elemental Accumulation in Some Marine Macrophytes (Mediterranean Sea Coast of Egypt)
}

\author{
N. Nassar ${ }^{1}$, A. Kravtsova ${ }^{2,3}$, M. Frontasyeva ${ }^{2}$, M. M. Sherif ${ }^{1}$ \\ ${ }^{1}$ Department of Physics, Faculty of Science, Cairo University, Giza, Egypt \\ ${ }^{2}$ FLNP JINR, Dubna, Russia \\ ${ }^{3}$ The A.O. Kovalevsky Institute of Marine Biological Research of RAS, Sevastopol, Russia \\ Email: nohanassar59@gmail, alexkravtsova@yandex.ua,marina@nf.jinr.ru,mmsherif@sci.cu.edu.eg
}

How to cite this paper: Nassar, N., Kravtsova, A., Frontasyeva, M. and Sherif, M.M. (2017) Neutron Activation Analyses Used to Study Elemental Accumulation in Some Marine Macrophytes (Mediterranean Sea Coast of Egypt). American Journal of Analytical Chemistry, 8, 395-405.

https://doi.org/10.4236/ajac.2017.86030

Received: May 10, 2017

Accepted: June 12, 2017

Published: June 15, 2017

Copyright (c) 2017 by authors and Scientific Research Publishing Inc. This work is licensed under the Creative Commons Attribution International License (CC BY 4.0).

http://creativecommons.org/licenses/by/4.0/

\begin{abstract}
The concentrations of $\mathrm{Na}, \mathrm{Mg}, \mathrm{Al}, \mathrm{S}, \mathrm{Cl}, \mathrm{K}, \mathrm{Ca}, \mathrm{Sc}, \mathrm{Ti}, \mathrm{V}, \mathrm{Cr}, \mathrm{Mn}, \mathrm{Fe}, \mathrm{Co}, \mathrm{Ni}$, $\mathrm{Zn}, \mathrm{As}$, Se Br, Rb, Sr, Zr, Mo, Ag, Sb, I, Cs, Ba, La, Sm, Eu, Tb, Yb, Hf, Ta, W, $\mathrm{Au}, \mathrm{Th}$ and $\mathrm{U}$ in 6 types of marine macrophytes (algae and seagrass): Gelidium pusillum (Stackhouse) Le Jolis, Ulva intestinalis Linnaeus, Amphiroa rigida J.V. Lamouroux, Hypnea sp., Cystoseira sp. and Posidonia oceanica (L.) Delile (seagrass) collected from 3 stations along the Mediterranean Sea coast of Egypt were determined using instrumental neutron activation analysis. The contents of elements in marine macrophytes indicated that they accumulated elements at different levels depending on their type of species (brown, red, green and seagrass) and the ambient water conditions. However, the concentrations of $\mathrm{Cr}, \mathrm{Co}, \mathrm{Ni}, \mathrm{Se}, \mathrm{Zr}, \mathrm{Mo}, \mathrm{Ag}, \mathrm{Cs}, \mathrm{La}, \mathrm{Sm}, \mathrm{Eu}, \mathrm{Yb}, \mathrm{Hf}, \mathrm{Ta}, \mathrm{Au}$ and $\mathrm{U}$ were very similar in all samples. In general the levels of classically investigated elements, particularly $\mathrm{Mn}, \mathrm{Fe}, \mathrm{Co}, \mathrm{Ni}$ and $\mathrm{Zn}$ determined in the macrophytes in the present study are lower or within the wide range of values previously reported for species of these genera sampled along the Egyptian Mediterranean coast.
\end{abstract}

\section{Keywords}

Algae and Seagrass, Elemental Analysis Mediterranean Sea, Neutron Activation Analysis

\section{Introduction}

With an estimated population of 132 million inhabitants that increases sharply 
during the summer tourist season, the Mediterranean coast, including its Egyptian part, is particularly subject to strong human pressure [1]. The western part of the Nile Delta Coast (Abu Qir Bay), which is polluted by industrial wastes from 22 different factories including food processing and canning, paper industry, fertilizer industry and textile manufacturing, is considered as hot spot area [2] [3]. Pollution of the marine environment with trace elements (TEs) remains a topical subject because some of these elements, not frequently monitored up to now (e.g. Sb, Mo, etc.) can be considered as environmental pollutants of "emerging concern" [4]. The monitoring of marine pollution using different bioindicator species provides several advantages [5] [6] when compared with chemical analysis of environmental matrices (i.e. water and sediments). A wide variety of species have been shown to be relevant indicators to assess the contamination status of marine ecosystems, where different species of seagrass and macroalgae are among the most used in the Mediterranean [4] [7].

During the last decades numerous studies have been carried out concerning trace element accumulation in marine macrophytes sampled along the Mediterranean coast of Egypt. However, data are mostly available for species of a few genera such as Ulva, and only a small number of elements, mainly $\mathrm{Cd}, \mathrm{Cu}, \mathrm{Cr}$, $\mathrm{Mn}, \mathrm{Co}, \mathrm{Ni}, \mathrm{Pb}$ and [2] [3] [8] [9] [10]. References concerning widespread macroalgae that could potentially be used as biomonitors and levels of the majority of elements are scarce. To extend the list of potential biomonitors in the study area and add data about accumulation of a wide range of elements, including major and rare earth elements, the aim of this work was to evaluate the concentrations of up to 39 elements in 6 species of macrophytes sampled in the coastal waters of Egypt (Mediterranean Sea) using neutron activation analysis (NAA).

\section{Materials and Methods}

\subsection{Study Area}

The samples were collected during summer 2015 in the coastal waters of the city of Alexandria and Marsa Matrouh city which are both situated on the Mediterranean coast of Egypt and are considered the main two cities and industrial zones on the north coast of Egypt. The sampling sites are presented in Figure 1. The first sampling site is located at Cleopatra beach, Marsa Matrouh city $\left(31^{\circ} 22^{\prime} 29.0^{\prime \prime} \mathrm{N}, 27^{\circ} 11^{\prime} 23.0^{\prime \prime} \mathrm{E}\right)$. It is characterized by big anthropogenic loading during summer period when the number of visitors to Marsa Matrouh may reach more than one million [10]. The second and third sampling sites are adjacent to Alexandria, the second largest city in Egypt and a major economic center, extending about $32 \mathrm{~km}$ to the north west of Nile Delta stretching over $70 \mathrm{~km}$ along the coast [11]. Alexandria's environmental problems have grown in severity as its population and associated urban and industrial development have increased since the beginning of the 20th century [12]. The second sampling site is located at Citadel beach $\left(31^{\circ} 12^{\prime} 49.6^{\prime \prime} \mathrm{N}, 29^{\circ} 53^{\prime} 01.1^{\prime \prime E}\right)$, about $4 \mathrm{~km}$ from Alexandria port, which is considered the main port in Egypt. Alexandria Port receives many types of containers (e.g., cement, coal, fertilizers, grain and flour, oil and oil 


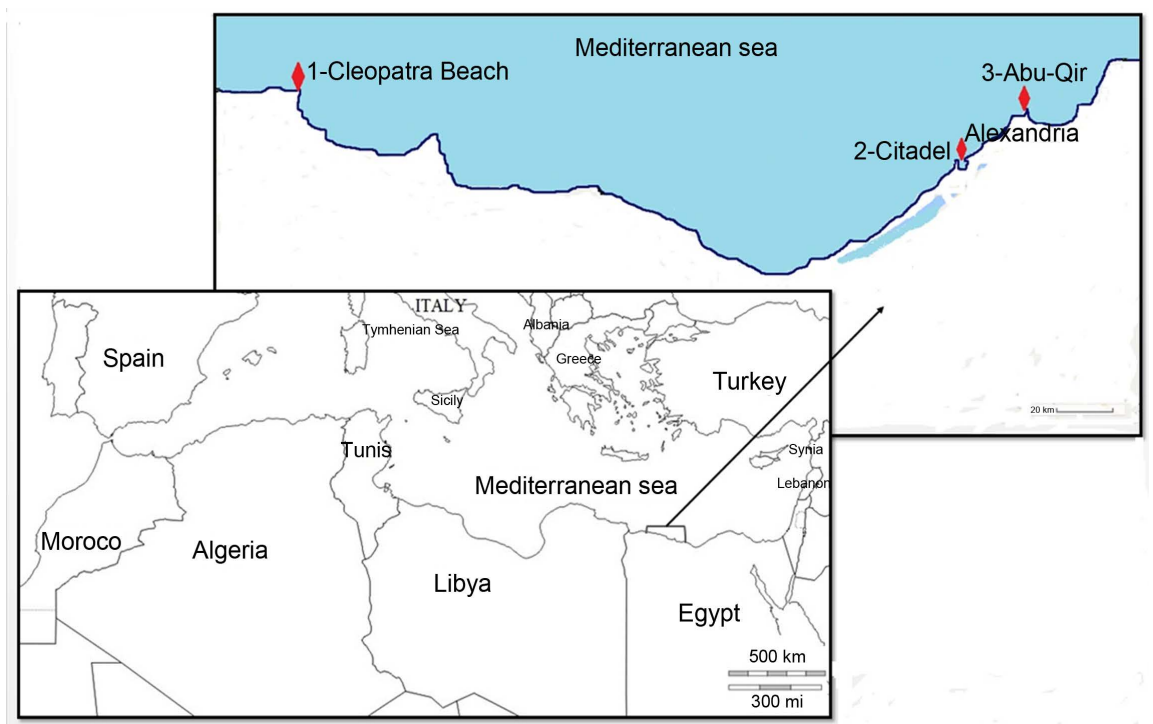

Figure 1. Sampling locations on the Mediterranean Sea in the north coast of Egypt.

products) (http://www.apa.gov.eg/) and it is affected by fishing and hatching activities [9]. The third sampling site is located at Abu-Qir bay $\left(31^{\circ} 19^{\prime} 40.4^{\prime \prime} \mathrm{N}\right.$, $30^{\circ} 03^{\prime} 45.0^{\prime \prime E}$ ) Abu Qir Bay is situated along the southeastern coast of Alexandria and is considered as a strongly contaminated area. It is subjected to several landbased sources, such as freshwater from the Rosetta mouth of the Nile River loaded by nutrients, Lake Edku effluent carrying heavy metals, pesticides, humic acids, and nutrients; and El-Tabia Pumping Station (TPS) contributing industrial and domestic wastes. The estimated amount of untreated sewage and industrial wastes from 22 different factories pumped to Abu-Qir Bay through TPS is of about 2 million $\mathrm{m}^{3} /$ day. The bay is also exposed to oil pollution from fishing boats, the activities of gas production liquefying and export field [3] [13] [14].

\subsection{Sampling and Sample Preparation}

The samples that were found attached to rocks were collected at 3 station (1-st Cystoseira sp. and Posidonia oceanica; 2-nd-Gelidium pusillum; 3-d-Hypnea sp., Ulva intestinalis, Amphiroa rigida) by hand on the depth 0.5 to $1.5 \mathrm{~m}$, rinsed with ambient water and cleaned from epiphytes, then kept in a polyethylene bags and transferred to the laboratory in an ice-box. In the laboratory samples were rinsed with distilled water [7] and dried till constant weight at $40^{\circ} \mathrm{C}$ during 24 hours then manually homogenized in agate mortar [15].

\subsection{Analysis}

Neutron activation analysis was performed in the radioanalytical laboratory at the pulsed fast reactor IBR-2 of the Frank Laboratory of Neutron Physics, JINR, Dubna, Russia [16]. For short irradiation samples of about $0.3 \mathrm{~g}$ were heat-sealed in polyethylene bags. For long irradiation samples of the same weight (about 0.3 g) were packed in aluminium cups. To determine the short lived isotopes ( $\mathrm{Al}, \mathrm{S}$, $\mathrm{Cl}, \mathrm{Ca}, \mathrm{Ti}, \mathrm{V}, \mathrm{Mn}, \mathrm{Mg}$, and I) conventional irradiation channel was used. Sam- 
ples were irradiated for $3 \mathrm{~min}$ and measured twice after 2 - $3 \mathrm{~min}$ and the second one for $20 \mathrm{~min}$ after 9 - $10 \mathrm{~min}$ of decay. Long-lived isotopes were determined using epithermal neutrons in cadmium-screened irradiation channel with neutron flux density Фepi. $=3.6 \times 10^{12} \mathrm{n} /\left(\mathrm{cm}^{2} \cdot \mathrm{s}\right)$. Samples were irradiated for $5 \mathrm{~d}$, repacked and then measured twice after $4-6$ and $20 \mathrm{~d}$ of decay, respectively. Measuring time varied from 1 to $5 \mathrm{~h}$. To process gamma spectra and to calculate concentrations of elements in the samples, software was used that was developed at FLNP JINR [17]. The errors in the determined concentrations were in the range of $5 \%-15 \%$ and $30 \%$ or greater for those elements (e.g. $\mathrm{Zr}, \mathrm{Mo}, \mathrm{Ag}, \mathrm{Au}$ ) which concentrations in the samples were at the level of detection. Quality control was ensured by simultaneous analysis of the examined samples and standard reference materials SRM 1632c (trace elements in coal, National Institute of Standard and Technology (NIST)), SRM 1633b (constituent elements in coal fly ash, NIST), 1547 (peach leaves, NIST), 690CC (calcareous soil, Food and Agriculture Organization of the United Nations), 1573a (tomato leaves, NIST), SRM 433 (marine sediments, International Atomic Energy Agency) and BCR 667 (estuarine sediment, Institute for Reference Materials and Measurements) irradiated in the same conditions together with the samples under investigation. The NAA data and certfied values of reference materials are given in Table 1.

\section{Results and Discussion}

For all collected samples the concentrations of $\mathrm{Na}, \mathrm{Mg}, \mathrm{Al}, \mathrm{S}, \mathrm{Cl}, \mathrm{K}, \mathrm{Ca}, \mathrm{Sc}, \mathrm{V}$, $\mathrm{Mn}, \mathrm{Fe}, \mathrm{Co}, \mathrm{Ni}, \mathrm{Zn}$, As, Se Br, Rb, Sr, Ag, Sb, I, Cs, Ba, Ta, Th, and U were determined while the content of $\mathrm{Ti}, \mathrm{Cr}, \mathrm{Zr}, \mathrm{Mo}, \mathrm{La}, \mathrm{Sm}, \mathrm{Eu}, \mathrm{Tb}, \mathrm{Yb}, \mathrm{Hf}, \mathrm{W}$ and $\mathrm{Au}$ in some species was below the level of detection (Table 2).

The concentration of major elements varied in a wide range depending on the species of macrophytes (from $1635 \mathrm{mg} / \mathrm{kg}$ for K in Posidonia oceanica to 246,500 $\mathrm{mg} / \mathrm{kg}$ for $\mathrm{Ca}$ in Amphiroa rigida). The highest concentration of $\mathrm{Na}$ and $\mathrm{S}$ were found in Hypnea sp., while the maximum values of $\mathrm{Cl}$ and $\mathrm{Ca}$ were determined in Ulva intestinalis and Amphiroa rigida, respectively. The concentration of $\mathrm{Mg}$ varied in a more narrow range, and their minimum and maximum contents differ in the samples by up to eight times. The results obtained for some trace elements varied in a wide range depending on the species of analyzed macrophyte (from $0.002 \mathrm{mg} / \mathrm{kg}$ for $\mathrm{Tb}$ in Hypnea sp. to $2100 \mathrm{mg} / \mathrm{kg}$ for $\mathrm{Sr}$ in Amphiroa rigida while the concentrations of $\mathrm{Cr}, \mathrm{Co}, \mathrm{Ni}, \mathrm{Se}, \mathrm{Zr}, \mathrm{Mo}, \mathrm{Ag}, \mathrm{Cs}, \mathrm{La}, \mathrm{Sm}, \mathrm{Eu}, \mathrm{Yb}, \mathrm{Hf}$, $\mathrm{Ta}, \mathrm{Au}$ and $\mathrm{U}$ were very similar in all samples (Figure 2).

The concentration of elements in the samples collected at the same station (Abo-Qir bay) are varied greatly too. Thus the content of $\mathrm{Na}, \mathrm{S}, \mathrm{Cl}, \mathrm{Ca}$ and $\mathrm{Sr}$ in Hypnea sp., Ulva intestinalis and Amphiroa rigida differ by more than 10 times, $\mathrm{Mg}, \mathrm{Ba}, \mathrm{Tb}$ and $\mathrm{Th}$ differ by up to 10 times. Nevertheless, the levels of such elements as Sc, Ti, V, Cr, Fe, Co, Ni, Zn, Se, Zr, Mo, Ag, Sb, I, Cs, La, Sm, Hf, Ta, $\mathrm{Au}$ and $\mathrm{U}$ are very similar in Hypnea sp., Ulva intestinalis and Amphiroa rigida and differ by up to 3 times. The accumulation rate of major and trace elements 
Table 1. Analysis of certified reference materials: certified and determined values, standard deviation.

\begin{tabular}{|c|c|c|c|c|}
\hline Element & $\begin{array}{c}\text { Determined concentration, } \\
\mu \mathrm{g} \times \mathrm{g}^{-1} \text { dry weight }\end{array}$ & $\begin{array}{c}\text { Certified concentration, } \\
\mu \mathrm{g} \times \mathrm{g}^{-1} \text { dry weight }\end{array}$ & $\begin{array}{c}\text { Standard } \\
\text { deviation, \% }\end{array}$ & SRM \\
\hline $\mathrm{Na}$ & 300 & 298.8 & 0.4 & $1632 \mathrm{c}$ \\
\hline $\mathrm{Mg}$ & 4326 & 4320 & 0.1 & 1547 \\
\hline $\mathrm{Al}$ & 9143 & 9150 & 0.1 & $1632 c$ \\
\hline$S$ & 13498 & 14620 & 7.7 & $1632 \mathrm{c}$ \\
\hline $\mathrm{Cl}$ & 590 & 600 & 1.67 & $1573 a$ \\
\hline K & 27045 & 27000 & 0.2 & $1573 a$ \\
\hline $\mathrm{Ca}$ & 15637 & 15600 & 0.2 & 1547 \\
\hline Sc & 14.64 & 14.6 & 0.2 & 433 \\
\hline $\mathrm{Ti}$ & 518 & 517 & 0.3 & $1632 c$ \\
\hline $\mathrm{V}$ & 23.7 & 23.72 & 0.1 & $1632 c$ \\
\hline $\mathrm{Cr}$ & 154 & 136 & 14 & 433 \\
\hline $\mathrm{Mn}$ & 132 & 131.8 & 0.2 & $1633 b$ \\
\hline $\mathrm{Fe}$ & 74492 & 77800 & 4.3 & $1633 b$ \\
\hline Co & 12.8 & 12.9 & 0.1 & 433 \\
\hline $\mathrm{Ni}$ & 39.3 & 39.4 & 0.1 & 433 \\
\hline $\mathrm{Zn}$ & 202 & 210 & 3.7 & $1633 \mathrm{~b}$ \\
\hline As & 18.92 & 18.9 & 0.1 & 433 \\
\hline $\mathrm{Se}$ & 10.3 & 10.26 & 0.4 & $1633 b$ \\
\hline $\mathrm{Br}$ & 17.1 & 18.7 & 8.5 & $1632 c$ \\
\hline $\mathrm{Rb}$ & 98.9 & 99.9 & 1.0 & 433 \\
\hline $\mathrm{Sr}$ & 301.6 & 302 & 0.1 & 433 \\
\hline $\mathrm{Zr}$ & 140 & 148 & 5.4 & 433 \\
\hline Mo & 0.43 & 0.46 & 6.5 & $1573 a$ \\
\hline $\mathrm{Ag}$ & 0.131 & 0.133 & 0.7 & 433 \\
\hline $\mathrm{Sb}$ & 1.95 & 1.96 & 0.1 & 433 \\
\hline I & 0.29 & 0.3 & 3.2 & 1547 \\
\hline Cs & 10.2 & 11 & 6.8 & $1633 \mathrm{~b}$ \\
\hline $\mathrm{Ba}$ & 67.56 & 67.5 & 0.1 & $1632 c$ \\
\hline $\mathrm{La}$ & 30.6 & 33.6 & 9.2 & 433 \\
\hline $\mathrm{Ce}$ & 168 & 190 & 11.5 & $1633 \mathrm{~b}$ \\
\hline $\mathrm{Sm}$ & 1.082 & 1.078 & 0.4 & $1632 c$ \\
\hline $\mathrm{Eu}$ & 1.34 & 1.18 & 13.7 & 433 \\
\hline $\mathrm{Tb}$ & 0.65 & 0.7 & 6 & 433 \\
\hline $\mathrm{Yb}$ & 1.56 & 1.57 & 0.6 & $690 \mathrm{cc}$ \\
\hline $\mathrm{Hf}$ & 3.82 & 3.66 & 4.6 & 433 \\
\hline $\mathrm{Ta}$ & 1.79 & 1.8 & 0.1 & $1633 \mathrm{~b}$ \\
\hline W & 0.481 & 0.480 & 0.2 & $1632 c$ \\
\hline $\mathrm{Au}$ & 0.015 & 0.016 & 6.3 & 667 \\
\hline Th & 9.77 & 9.78 & 0.1 & 433 \\
\hline U & 0.512 & 0.513 & 0.1 & $1632 \mathrm{c}$ \\
\hline
\end{tabular}


Table 2. Concentrations of elements (mean \pm standard error, in $\mu \mathrm{g} \cdot \mathrm{g}^{-1}$ dry weight) in marine macrophytes (the Mediterranean coast of Egypt).

\begin{tabular}{|c|c|c|c|c|c|c|c|c|c|c|c|c|}
\hline Type of algae & Phylum & $\begin{array}{c}\mathrm{Na} \\
\mathrm{mg} / \mathrm{kg}\end{array}$ & $\begin{array}{c}\mathrm{Mg} \\
\mathrm{mg} / \mathrm{kg}\end{array}$ & $\begin{array}{c}\mathrm{Al} \\
\mathrm{mg} / \mathrm{kg}\end{array}$ & $\begin{array}{c}\mathrm{S} \\
\mathrm{mg} / \mathrm{kg}\end{array}$ & $\begin{array}{c}\mathrm{Cl} \\
\mathrm{mg} / \mathrm{kg}\end{array}$ & $\begin{array}{c}\mathrm{K} \\
\mathrm{mg} / \mathrm{kg}\end{array}$ & $\begin{array}{c}\mathrm{Ca} \\
\mathrm{mg} / \mathrm{kg}\end{array}$ & $\begin{array}{c}\mathrm{Sc} \\
\mathrm{mg} / \mathrm{kg}\end{array}$ & $\begin{array}{c}\mathrm{Ti} \\
\mathrm{mg} / \mathrm{kg}\end{array}$ & $\begin{array}{c}\mathrm{V} \\
\mathrm{mg} / \mathrm{kg}\end{array}$ & $\begin{array}{c}\mathrm{Cr} \\
\mathrm{mg} / \mathrm{kg}\end{array}$ \\
\hline $\begin{array}{l}\text { Gelidium } \\
\text { pusillum }\end{array}$ & Rhodophyta & $30,400 \pm 600$ & $9000 \pm 200$ & $72.7 \pm 7.0 \quad 8$ & $82,600 \pm 21,200$ & $58,300 \pm 4400$ & $42,300 \pm 3900$ & $5000 \pm 400$ & $0.010 \pm 0.003$ & $73 \pm 37$ & $3.7 \pm 0.3$ & $3.28 \pm 0.94$ \\
\hline $\begin{array}{c}\text { Ulva } \\
\text { Intestinalis }\end{array}$ & Chlorophyta & $50,000 \pm 1000$ & $28,400 \pm 700$ & $483.0 \pm 14.0$ & $66,500 \pm 17,400$ & $118,000 \pm 8900$ & $028,200 \pm 2600$ & $8400 \pm 600$ & $0.090 \pm 0.010$ & & $3.6 \pm 0.3$ & \\
\hline $\begin{array}{l}\text { Amphiroa } \\
\text { rigida }\end{array}$ & Rhodophyta & $5400 \pm 100$ & $42,000 \pm 1000$ & $678.0 \pm 17.0$ & $7000 \pm 3300$ & $7900 \pm 600$ & $6200 \pm 6002$ & $246,500 \pm 16,30$ & $00.100 \pm 0.010$ & $110 \pm 21$ & $3.7 \pm 0.2$ & $1.52 \pm 0.66$ \\
\hline Cystoseira sp. & Ochrophyta & $10,500 \pm 200$ & $10,200 \pm 200$ & $83.2 \pm 3.0$ & $28,700 \pm 7600$ & $29,500 \pm 2200$ & $46,700 \pm 3700$ & $19,000 \pm 1300$ & $0.030 \pm 0.010$ & & $13.2 \pm 0.5$ & $1.59 \pm 0.50$ \\
\hline $\begin{array}{c}\text { Posidonia } \\
\text { oceanica }\end{array}$ & Tracheophyta & $16,400 \pm 300$ & $5700 \pm 150$ & $431.0 \pm 11.0$ & $11,900 \pm 4100$ & $36,400 \pm 2700$ & $1600 \pm 900$ & $14,250 \pm 1000$ & $0.140 \pm 0.020$ & $40 \pm 24$ & $1.4 \pm 0.1$ & $3.34 \pm 0.39$ \\
\hline Type of algae & Phylum & Mn mg/kg & $\mathrm{Fe} \mathrm{mg} / \mathrm{kg}$ & Co $\mathrm{mg} / \mathrm{kg}$ & $\mathrm{Ni} \mathrm{mg} / \mathrm{kg}$ & $\mathrm{Zn} \mathrm{mg/kg}$ & As $\mathrm{mg} / \mathrm{kg}$ & Se $\mathrm{mg} / \mathrm{kg}$ & $\mathrm{Br} \mathrm{mg} / \mathrm{kg} \mathrm{F}$ & $\mathrm{Rb} \mathrm{mg} / \mathrm{kg}$ & $\mathrm{Sr} \mathrm{mg} / \mathrm{kg}$ & $\mathrm{Zr} \mathrm{mg/kg}$ \\
\hline $\begin{array}{l}\text { Gelidium } \\
\text { pusillum }\end{array}$ & Rhodophyta & $18.5 \pm 1.4$ & $203 \pm 15$ & $0.23 \pm 0.01$ & $2.31 \pm 0.24$ & $18.30 \pm 0.60$ & $8.09 \pm 0.22$ & $0.47 \pm 0.03$ & $980 \pm 117$ & $17.8 \pm 3.3$ & $146 \pm 9$ & \\
\hline $\begin{array}{c}\text { Ulva } \\
\text { intestinalis }\end{array}$ & Chlorophyta & $24.5 \pm 1.0$ & $533 \pm 32$ & $0.22 \pm 0.01$ & $1.74 \pm 0.21$ & $11.80 \pm 0.40$ & $8.58 \pm 0.45$ & $0.19 \pm 0.03$ & $890 \pm 106$ & $8.5 \pm 1.6$ & $11 \pm 7$ & $2.74 \pm 1.09$ \\
\hline $\begin{array}{l}\text { Amphiroa } \\
\text { rigida }\end{array}$ & Chlorophyta & $48.6 \pm 2.3$ & $292 \pm 18$ & $0.28 \pm 0.01$ & $0.85 \pm 0.13$ & $19.70 \pm 0.60$ & $2.09 \pm 0.06$ & $0.11 \pm 0.04$ & $200 \pm 24$ & $2.7 \pm 0.5$ & $2100 \pm 129$ & $3.90 \pm 1.28$ \\
\hline Cystoseira sp. & Ochrophyta & $5.4 \pm 0.7$ & $72 \pm 9$ & $0.19 \pm 0.01$ & $1.26 \pm 0.19$ & $65.00 \pm 1.70$ & $45.90 \pm 0.90$ & $0.10 \pm 0.03$ & $455 \pm 54$ & $16.9 \pm 3.1$ & $1505 \pm 93$ & $3.53 \pm 1.27$ \\
\hline $\begin{array}{c}\text { Posidonia } \\
\text { oceanica }\end{array}$ & Tracheophyta & $11.3 \pm 1.0$ & $437 \pm 23$ & $0.27 \pm 0.01$ & $2.22 \pm 0.18$ & $2.07 \pm 0.17$ & $3.22 \pm 0.13$ & $0.56 \pm 0.03$ & $412 \pm 50$ & $0.7 \pm 0.1$ & $345 \pm 21$ & $3.27 \pm 1.13$ \\
\hline Type of algae & Phylum & $\begin{array}{c}\mathrm{Mo} \\
\mathrm{mg} / \mathrm{kg}\end{array}$ & $\begin{array}{c}\mathrm{Ag} \\
\mathrm{mg} / \mathrm{kg}\end{array}$ & $\begin{array}{c}\mathrm{Sb} \\
\mathrm{mg} / \mathrm{kg}\end{array}$ & $\begin{array}{c}\mathrm{I} \\
\mathrm{mg} / \mathrm{kg}\end{array}$ & $\begin{array}{c}\mathrm{Cs} \\
\mathrm{mg} / \mathrm{kg}\end{array}$ & $\begin{array}{c}\mathrm{Ba} \\
\mathrm{mg} / \mathrm{kg}\end{array}$ & $\begin{array}{c}\mathrm{La} \\
\mathrm{mg} / \mathrm{kg}\end{array}$ & $\begin{array}{c}\mathrm{Ce} \\
\mathrm{mg} / \mathrm{kg}\end{array}$ & $\begin{array}{c}\mathrm{Sm} \\
\mathrm{mg} / \mathrm{kg}\end{array}$ & $\begin{array}{c}\mathrm{Eu} \\
\mathrm{mg} / \mathrm{kg}\end{array}$ & $\begin{array}{c}\mathrm{Tb} \\
\mathrm{mg} / \mathrm{kg}\end{array}$ \\
\hline $\begin{array}{l}\text { Gelidium } \\
\text { pusillum }\end{array}$ & Rhodophyta & & $0.140 \pm 0.000$ & $0.050 \pm 0.003$ & $112 \pm 16$ & $0.020 \pm 0.002$ & $4.20 \pm 0.52$ & & & & & \\
\hline Hypnea & Rhodophyta & & $0.020 \pm 0.010$ & $0.030 \pm 0.002$ & $88 \pm 13$ & $0.010 \pm 0.002$ & $1.85 \pm 0.42$ & $0.13 \pm 0.10$ & & $0.05 \pm 0.03$ & & $0.002 \pm 0.001$ \\
\hline $\begin{array}{c}\text { Ulva } \\
\text { intestinalis }\end{array}$ & Chlorophyta & $1.04 \pm 0.49$ & $0.010 \pm 0.002$ & $0.030 \pm 0.002$ & $41 \pm 6$ & $0.030 \pm 0.002$ & $5.04 \pm 0.63$ & & & & & \\
\hline $\begin{array}{l}\text { Amphiroa } \\
\text { rigida }\end{array}$ & Chlorophyta & $0.60 \pm 0.20$ & $0.050 \pm 0.002$ & $0.010 \pm 0.002$ & $68 \pm 10$ & $0.020 \pm 0.002$ & $13.20 \pm 0.70$ & $0.37 \pm 0.04$ & $5.72 \pm 0.690$ & $0.09 \pm 0.010$ & $0.03 \pm 0.020$ & $20.010 \pm 0.002$ \\
\hline Cystoseira sp. & Ochrophyta & $1.48 \pm 0.94$ & $0.010 \pm 0.003$ & $0.090 \pm 0.010$ & $140 \pm 21$ & $0.020 \pm 0.002$ & $29.50 \pm 2.00$ & $0.17 \pm 0.06$ & & & & \\
\hline $\begin{array}{c}\text { Posidonia } \\
\text { oceanica }\end{array}$ & Tracheophyta & $0.63 \pm 0.39$ & $0.013 \pm 0.004$ & $0.552 \pm 0.0164$ & $819 \pm 120$ & $0.020 \pm 0.002$ & $2.42 \pm 0.28$ & $0.27 \pm 0.13$ & $4.13 \pm 0.610$ & $0.05 \pm 0.020$ & $20.03 \pm 0.020$ & $20.010 \pm 0.020$ \\
\hline Type of algae & Phylum & $\mathrm{Yb} \mathrm{mg} / \mathrm{kg}$ & $\mathrm{Hf} \mathrm{mg} / \mathrm{kg}$ & $\mathrm{Ta} \mathrm{mg} / \mathrm{kg}$ & $\mathrm{W} \mathrm{mg} / \mathrm{kg}$ & Au mg/kg & Th $\mathrm{mg} / \mathrm{kg}$ & $\mathrm{U} \mathrm{mg} / \mathrm{kg}$ & & & & \\
\hline $\begin{array}{l}\text { Gelidium } \\
\text { pusillum }\end{array}$ & Rhodophyta & & & $0.010 \pm 0.002$ & $3.68 \pm 1.25$ & $0.010 \pm 0.004$ & $0.010 \pm 0.002$ & $0.31 \pm 0.10$ & & & & \\
\hline Hypnea & Rhodophyta & & & $0.003 \pm 0.001$ & & $0.010 \pm 0.003$ & $0.010 \pm 0.004$ & $0.23 \pm 0.07$ & & & & \\
\hline $\begin{array}{c}\text { Ulva } \\
\text { intestinalis }\end{array}$ & Chlorophyta & & $0.05 \pm 0.02$ & $0.010 \pm 0.002$ & & $0.010 \pm 0.004$ & $0.030 \pm 0.002$ & $0.25 \pm 0.06$ & & & & \\
\hline $\begin{array}{l}\text { Amphiroa } \\
\text { rigida }\end{array}$ & Chlorophyta & $0.04 \pm 0.01$ & $0.05 \pm 0.01$ & $0.010 \pm 0.002$ & & & $0.050 \pm 0.004$ & $0.28 \pm 0.02$ & & & & \\
\hline Cystoseira sp. & Ochrophyta & & $0.04 \pm 0.01$ & $0.010 \pm 0.002$ & & & $0.020 \pm 0.002$ & $0.76 \pm 0.05$ & & & & \\
\hline $\begin{array}{c}\text { Posidonia } \\
\text { oceanica }\end{array}$ & Tracheophyta & $0.08 \pm 0.05$ & $0.07 \pm 0.02$ & $0.010 \pm 0.002$ & $1.68 \pm 0.63$ & & $0.080 \pm 0.004$ & $0.82 \pm 0.05$ & & & & \\
\hline
\end{tabular}

by marine macrophytes depends on many factors, where the taxonomic identity of the plant and concentration of elements in the ambient environment are among the most important ones. The collected marine macrophytes represent three algal classes and seagrass species: Chlorophyceae (Ulva intestinalis), Rhodophyceae (Gelidium pussilum, Amphiroa rigida, Hypnea sp.), Phaeophyceae (Cystoseira sp.) and Tracheophyta (Posidonia oceanica).

The maximum values of $\mathrm{Cl}$ and $\mathrm{Fe}$ and the lowest content of $\mathrm{I}$ are found in Ulva intestinalis. Our levels of $\mathrm{Na}, \mathrm{K}$ and $\mathrm{Ca}$ are 2 - 3 higher than the data reported by El-Said (2013) for Ulva lactuca collected from Abo-Qir bay, Egypt. 


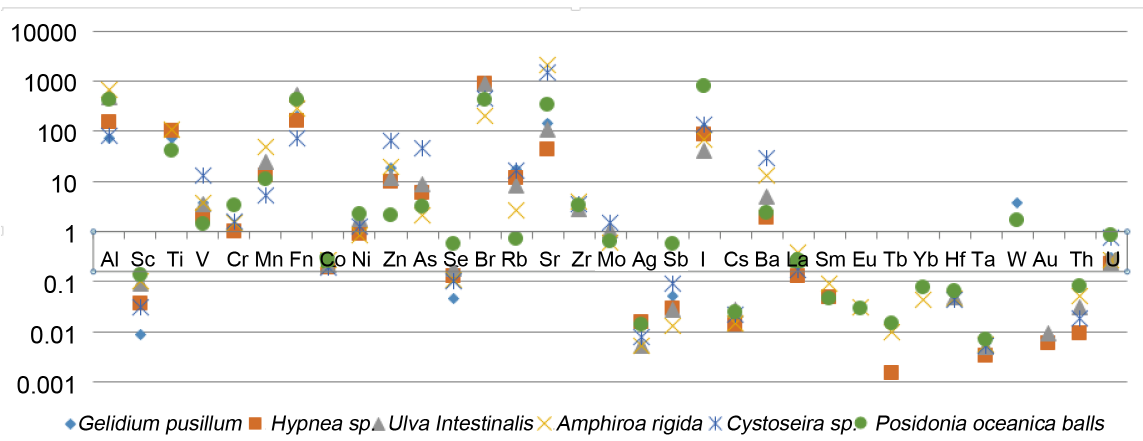

Figure 2. Concentration of trace elements in $\mathrm{mg} / \mathrm{kg}$ dry weight in marine algae and seagrass collected from the Mediterranean coast of Egypt.

Our levels of Mn in Ulva intestinalis are 2 - 2.5 times higher than the data of other authors, while the content of $\mathrm{Fe}, \mathrm{Co}, \mathrm{Ni}$ and $\mathrm{Zn}$ is up to 10 times lower than the concentrations reported for the species of Ulva collected along the Mediterranean coast of Egypt (Table 3).

Gelidium pussilum is characterized by the highest levels of $\mathrm{Ni}, \mathrm{Br}$ and $\mathrm{Rb}$ and the lowest values of Al, Ca and Sc. The contents of $\mathrm{Na}(21,000 \mu \mathrm{g} / \mathrm{g}), \mathrm{Ni}$, and $\mathrm{Zn}$ (Table 3) reported by Shams El Din and El-Sherif (2012) [18] for Gelidium corneum sampled along the western coast of Alexandria are similar to our data, while the concentrations of $\mathrm{K}(2700 \mu \mathrm{g} / \mathrm{g})$ and $\mathrm{Ca}(26,000 \mu \mathrm{g} / \mathrm{g})$ are an order of magnitude lower and higher, respectively, than our results.

Hypnea sp. is characterized by the highest contents of $\mathrm{Na}$ and $\mathrm{S}$ and the lowest levels of $\mathrm{Cr}, \mathrm{Sr}, \mathrm{La}, \mathrm{Ta}$, and $\mathrm{Tb}$. Our results obtained for major elements (except for $\mathrm{Ca}$ ) are 2 - 3 times higher than the data reported by El-Said (2013) [9] for Hypnea musciformis collected from Abo-Quir bay, Egypt. The determined concentrations of $\mathrm{Fe}$ and As in Hypnea sp. are in agreement with the reported data for species of Mediterranean Hypnea, while in most cases our contents of $\mathrm{Co}, \mathrm{Ni}$, and $\mathrm{Zn}$ are one order of magnitude lower than the results of other authors (Table 3).

Amphiroa rigida is characterized by the highest levels of $\mathrm{Mg}, \mathrm{Al}, \mathrm{Ca}, \mathrm{Ti}, \mathrm{Mn}$, $\mathrm{Sr}, \mathrm{La}$ and $\mathrm{Sm}$ and the lowest values of $\mathrm{Na}, \mathrm{S}, \mathrm{Cl}, \mathrm{Ni}, \mathrm{As}, \mathrm{Br}, \mathrm{Mo}$ and $\mathrm{Sb}$. The results obtained for $\mathrm{Na}$ and $\mathrm{K}$ are in agreement with the data reported by El-Said (2013) [9] for the species of the same family Corallinaceae (Jania rubens ) collected from Abo-Quir bay, while our levels of $\mathrm{Mg}$ and $\mathrm{Ca}$ are 10 and 100 times higher, respectively, than the data of the same author. The content of $\mathrm{Mn}, \mathrm{Fe}$ and $\mathrm{Zn}$ are similar to the values reported by other authors for Jania rubens sampled along the Mediterranean coast of Egypt. Our levels of Co and Ni are up to one order of magnitude lower than the literature data (Table 3).

The maximum values of $\mathrm{K}, \mathrm{V}, \mathrm{Zn}, \mathrm{As}, \mathrm{Mo}$ and $\mathrm{Ba}$ and the lowest contents of $\mathrm{Mn}$ and $\mathrm{Fe}$ are found in Cystoseira sp. our concentrations of $\mathrm{Na}$ and $\mathrm{Ca}$ are in agreement with the data reported by Shams El Din and El-Sherif (2012) [18] for Cystoseira spinosa sampled along the western coast of Alexandria, Egypt, while our value for $\mathrm{K}$ is 23 times higher. Also our levels of major elements $(\mathrm{Na}, \mathrm{Mg}, \mathrm{Cl}$, $\mathrm{K}, \mathrm{Ca}, \mathrm{Sr}$ ) and halogens $(\mathrm{Br}, \mathrm{I})$ are similar to the published results for Cystoseira 
Table 3. Concentration of some trace elements (in $\mu \mathrm{g} \times \mathrm{g}^{-1}$ dry weight) in marine macrophytes (the Mediterranean Sea).

\begin{tabular}{|c|c|c|c|c|c|c|c|c|}
\hline Element & $\begin{array}{c}\text { Gelidium } \\
\text { sp. }\end{array}$ & $\begin{array}{c}\text { Hypnea } \\
s p .\end{array}$ & Ulva sp. & Corallinales & Cystoseira sp. & Posidonia sp. & Location and date of sampling & Reference \\
\hline \multirow{4}{*}{$\mathrm{Cr}$} & - & - & - & - & 1.59 & 3.34 & Marsa Matruh, Mediterranean Sea, 2014 & This study \\
\hline & - & - & - & - & 11.9 & 33.3 & Tartous, Syria, Mediterranean Sea, 1999 & [7] \\
\hline & - & - & - & - & 0.32 & - & Sicily, Italy, Mediterranean Sea, 2004 & [19] \\
\hline & - & - & - & - & - & 0.184 & Calvi, Corsica, France, Mediterranean Sea, 2010 & {$[4]$} \\
\hline \multirow{4}{*}{$\mathrm{Fe}$} & 203 & 165 & 533 & 292 & - & - & Alexandria, Mediterranean Sea, 2014 & This study \\
\hline & - & - & - & - & 72 & 437 & Marsa Matruh, Cleopatra beach 2014 & This study \\
\hline & 410 & - & - & 222 & 73 & 396 & Marsa Matruh,Mediterranean Sea, 2009-2010 & [10] \\
\hline & - & - & 525 & 467 & - & - & Alexandria, Mediterranean Sea, 2005 & [8] \\
\hline \multirow{6}{*}{ Co } & - & 0.20 & 0.22 & 0.28 & - & - & Alexandria Mediterranean Sea, 2014 & This study \\
\hline & - & - & - & - & 0.19 & - & Marsa Matrouh, Mediterranean Sea, 2014 & This study \\
\hline & - & - & 7.08 & 16.6 & - & - & Eastern harbor, Mediterranean Sea, 2005 & [8] \\
\hline & - & - & 3.60 & 2.95 & - & - & Abu-Qir, Alexandria, Mediterranean Sea, 2008 & [2] \\
\hline & - & 2.07 & 1.12 & 8.52 & - & - & $\begin{array}{l}\text { Abu-Qir, Alexandria, Mediterranean Sea, } \\
2008-2010\end{array}$ & [3] \\
\hline & - & - & 0.93 & - & 3.43 & - & Tartous, Syrian coast, Mediterranean Sea, 1999 & [7] \\
\hline \multirow{5}{*}{$\mathrm{Ni}$} & 2.31 & 0.89 & 1.74 & 0.85 & - & - & Alexandria, Mediterranean Sea, 2014 & This study \\
\hline & - & - & - & - & 1.27 & 2.22 & Marsa Matruh, Mediterranean Sea, 2014 & This study \\
\hline & 4.07 & - & 17 & 3.94 & 5.41 & 4.9 & Marsa Matruh, Mediterranean Sea, 2009-2010 & [10] \\
\hline & - & 5.85 & 3.64 & 12 & - & - & Abu-Qir, Alex.,2008-2010 & [3] \\
\hline & 7.46 & - & - & - & 6.56 & - & Alexandria, Mediterranean Sea, 2006 & [18] \\
\hline \multirow{13}{*}{$\mathrm{Zn}$} & 18 & 9.87 & 11.8 & 19.65 & - & - & Alexandria, Mediterranean Sea, 2014 & This study \\
\hline & - & - & - & - & 65 & 2.065 & Marsa Matruh, Mediterranean Sea, 2014 & This study \\
\hline & 42 & - & - & - & - & 12.34 & Marsa Matruh, Mediterranean Sea, 2009-2010 & [10] \\
\hline & - & - & 57.4 & - & - & - & Abu-Qir, Alexandria, Mediterranean Sea, 2006 & [2] \\
\hline & - & - & 97.5 & 2.37 & - & - & Abu-Qir, Alexandria, Mediterranean Sea, 2007 & [2] \\
\hline & - & - & 13.93 & 13.46 & - & - & Abu-Qir, Alexandria, Mediterranean Sea, 2008 & [2] \\
\hline & - & - & 10.0 & 12.54 & - & - & Abu-Qir, Alexandria, Mediterranean Sea, 2009 & [2] \\
\hline & - & 15.04 & - & - & - & - & Abu-Qir, Alex., 2008-2010 & [3] \\
\hline & 19.64 & - & - & - & 18.01 & - & $\begin{array}{l}\text { Western coast, Alexandria, } \\
\text { Mediterranean Sea, } 2006\end{array}$ & [18] \\
\hline & - & - & - & - & 26.2 & - & Sicily, Italy, Mediterranean Sea, 2004 & [19] \\
\hline & - & - & - & - & - & 107 & Calvi, Corsica, France, 2010 & [4] \\
\hline & - & 95.1 & 108.7 & - & 101.7 & - & Thessaloniki, Greece, 2007 & [21] \\
\hline & - & - & 35.92 & 17.17 & 11.17 & - & Tartous and Ras sharma, Sryia, 1998-1999 & [7] \\
\hline \multirow{5}{*}{ As } & - & 5.75 & 8.58 & - & - & - & Alexandria, Mediterranean Sea, 2014 & This study \\
\hline & - & - & - & - & 46 & 3.13 & Marsa Matruh, Mediterranean Sea, 2014 & This study \\
\hline & - & - & - & - & - & 0.92 & Calvi, Corsica, France, 2010 & [4] \\
\hline & - & 2.59 & 2.05 & - & 46 & - & Thessaloniki, Greece, 2007 & [20] \\
\hline & - & - & - & - & 5.95 & 29 & Tartous, Syria, 2000 & [7] \\
\hline
\end{tabular}


sp. collected along the Syrian coast of the Mediterranean Sea [7] differing only by a factor of $1.5-2.0$ Level of Fe detected in this survey is in good agreement with the data reported for the species of Cystoseira sampled along the Mediterranean coast of Egypt, while our content of $\mathrm{Ni}$ is about 5 times lower.

Posidonia oceanica is characterized by the highest level of Sc, Cr, Se, Sb, I, Hf, $\mathrm{Th}$ and $\mathrm{U}$ and the lowest values of $\mathrm{K}, \mathrm{Ti}, \mathrm{V}, \mathrm{Zn}$ and $\mathrm{Rb}$. Our concentration of $\mathrm{Na}$, $\mathrm{K}$ and $\mathrm{Ca}$ are 2 - 3 times lower than the data reported by Shams El Din and El-Sherif (2012) [18] for Posidonia oceanica collected along the western Egyptian Mediterranean coast. The levels of $\mathrm{Fe}$ and $\mathrm{Ni}$ determined in this survey are in agreement with the results of Khaled (2014) [10] published for Posidonia oceanica collected near Marsa Matruh, Egypt, Mediterranean Sea.

In general the levels of $\mathrm{Mn}, \mathrm{Fe}, \mathrm{Co}, \mathrm{Ni}$ and $\mathrm{Zn}$ observed in Ulva intestinalis, Gelidium pussilum, Amphiroa rigida, Hypnea sp., Cystoseira sp. and Posidonia oceanica in the present study are within the wide range of those previously reported for species of these genera sampled along the Egyptian Mediterranean coast (see Table 3). References concerning other trace and major elements in studied seaweeds are too scarce to establish comparisons.

The present results indicate that the accumulation of several elements in seaweeds is largely related to the phylogenetic origin of the species, which determines the biochemical composition of macroalgae. Thus, brown algae (in our study-Cystoseira sp.) usually accumulate more As, Sr and U than other taxonomic groups. High levels of as in brown algae are due to high phosphate concentrations in these macroalgae [21], as seaweeds take up and bioaccumulate arsenate from seawater as a phosphorus analogue [22]. High Sr concentrations in brown macroalgae are related to the cell wall polysaccharide alginate (constitute about $10 \%-40 \%$ of brown algae dry weight), as the main accumulation mechanism for $\mathrm{Sr}$ in brown algae is an ion exchange between seawater and alginate [20]. High concentration of $\mathrm{Ca}$ (about $25 \%$ of dry weight) in Amphiroa rigida could be explained by calcareous deposits contained within the cell walls which are typical for all algae of the order Corallinales. Elevated levels of Sr in Amphiroa rigida when compared to other studied macrophytes are related to high content of $\mathrm{Ca}$ which geochemical and biochemical characteristics are similar to those of Sr [23].

However, high concentrations of some trace elements in macrophytes may also be explained by their elevated level in the water area of sampling. Thus the maximum contents of V, Zn, Mo in Cystoseira sp. and $\mathrm{Cr}$ and $\mathrm{Ni}$ in Gelidium pussilum are likely due to relatively high level of pollution of sampling sites.

\section{Conclusion}

The concentrations of more than 30 elements that were rarely or never studied as well as the levels of classically investigated $\mathrm{Mn}, \mathrm{Fe}, \mathrm{Co}, \mathrm{Ni}$ and $\mathrm{Zn}$ in 6 species of marine macrophytes sampled along the Egyptian coast of the Mediterranean Sea were determined using neutron activation analysis. The results obtained for major and some trace elements varied within a wide range depending on the 
species of analyzed macrophyte, while the concentrations of $\mathrm{Cr}, \mathrm{Co}, \mathrm{Ni}, \mathrm{Se}, \mathrm{Zr}$, $\mathrm{Mo}, \mathrm{Ag}, \mathrm{Cs}, \mathrm{La}, \mathrm{Sm}, \mathrm{Eu}, \mathrm{Yb}, \mathrm{Hf}, \mathrm{Ta}, \mathrm{Au}$ and $\mathrm{U}$ were very similar in all samples. The contents of $\mathrm{Na}, \mathrm{S}, \mathrm{Cl}, \mathrm{Ca}$ and $\mathrm{Sr}$ in Hypnea sp., Ulva intestinalis and Amphiroa rigida sampled at the same station (Abo-Qir bay) differ by more than 10 times; $\mathrm{Mg}, \mathrm{Ba}, \mathrm{Tb}$ and $\mathrm{Th}$ differ by up to 10 times indicating that the accumulation of these elements is closely related to species biochemical composition, thallus morphology, or growth strategy. Our results indicate that Cystoseira sp. is a strong accumulator of As, $\mathrm{Sr}$ and $\mathrm{U}$, and Amphiroa rigida of $\mathrm{Ca}$ and $\mathrm{Sr}$. The studied species of macrophytes might be regarded as potential biomonitors for the elements concerned along the Egyptian coast of the Mediterranean Sea. Nevertheless, future investigations should be conducted in water areas with different levels of anthropogenic pollution, including relatively pristine areas, to reveal other accumulation properties of the macrophytes studied.

\section{References}

[1] Richir, J., Salivas-Decaux, M., Lafabrie, C., Lopez, Y., Royo, C., Gobert, S., Pergent, G. and Pergent-Martini, C. (2015) Bioassessment of Trace Element Contamination of Mediterranean Coastal Waters Using the Seagrass Posidonia oceanica. Journal of Environmental Management, 151, 486-499. https://doi.org/10.1016/j.jenvman.2014.11.015

[2] Abdallah, M.A.M. (2010) Heavy Metals Monitoring in Marine Seaweeds South Eastern Mediterranean Sea of Egyptian Coast, 2006-2009. Proceeding of the 4 th $\mathrm{Me}$ diterranean Symposium on Marine Vegetation, Yasmine-Hammamet, 2-4 December 2010.

[3] Shams El-Din, N.G., Mohamedein, L.I. and El-Moselhy, M.Kh. (2014) Seaweeds as Bioindicators of Heavy Metals off a Hot Spot Area on the Egyptian Mediterranean Coast during 2008-2010. Environmental Monitoring and Assessment, 186, 58655881. https://doi.org/10.1007/s10661-014-3825-3

[4] Richir, J. and Gobert, S. (2014) A Reassessment of the Use of Posidonia oceanica and Mytilus galloprovinicialis to Biomonitor the Coastal Pollution of Trace Elements: New Tools and Trips. Marin Pollution Bulletin, 89, 390-406.

https://doi.org/10.1016/j.marpolbul.2014.08.030

[5] Phillips, D. and Rainbow, Ph. (1993) The Biomonitoring of Trace Metals and Radionuclides. In: Biomonitoring of Trace Aquatic Contaminants, Springer, Netherlands, 79-132.

[6] Strezov, A. and Nonova, S. (2005) Environmental Monitoring of Heavy Metals in Bulgarian Black Sea Green Algae. Environmental Monitoring and Assessment, 105, 99-100. https://doi.org/10.1007/s10661-005-3158-3

[7] Al-Masri, M.S., Mmish, S. and Budier, S. (2003) Radionuclides and Trace Metals in Eastern Mediterranean Sea Algae. Journal of Radiochemistry, 67, 157-168. https://doi.org/10.1016/s0265-931x(02)00177-7

[8] Abdallah, M.A.M. and Abdallah, A.M.A. (2008) Biomonitoring Study of Heavy Metals in Biota and Sediments in South Eastern Coast of Mediterranean Sea, Egypt. Environmental Monitoring and Assessment, 146, 139-145. https://doi.org/10.1007/s10661-007-0066-8

[9] El-Said, G.F. (2013) Bioaccumulation of Key Metals and Other Contaminants by Seaweeds from the Egyptian Mediterranean Sea Coast in Relation to Human Risk. 
Human and Ecological Risk Assessment. An International Journal, 19, 1285-1305.

[10] Khaled, A., Hessein, A., Abdel-Halim, A.M. and Morsy, F.M. (2014) Distribution of Heavy Metals in Seaweeds Collected Along Marsa-Matrouh Beaches, Egyptian Mediterranean Sea. Egyptian Journal of Aquatic Research, 40, 363-371.

https://doi.org/10.1016/j.ejar.2014.11.007

[11] Morcos, S., Tongring, N., Halim, Y., El-Abbadi, M. and Awad, H. Towards Integrated Management of Alexandria's Coastal Heritage.

http://www.unesco.org/csi/pub/papers2/alex.pdf

[12] Halim, Y. and Abou Shouk, F. (2000) Human Impacts on Alexandria's Marine Environment. In: Mostafa, M.H., et al., Eds., Underwater Archaeology and Coastal Management. Focus on Alexandria, Coastal Management Sourcebooks 2, UNESCO, Paris, 137-139.

[13] Emam, W.M., Saad, A.El-H.A., El-Moselhy, K.M. and Owen, N.A. (2013) Evaluation of Water Quality of Abu-Qir Bay, Mediterranean Coast, Egypt. International Journal of Environmental Science and Engineering (IJESE), 4, 47-54.

[14] El-tawil, B.A.H. and Khalil, A.N. (1983) Chemical Constituents of Some Algal Species from Abu-Qir Bay, Egypt. Journal of Factuality of Marine Science, 3, 1404H.

[15] Kravtsova, A.V., Milchkova, N.A. and Frontasyeva, M. (2015) Levels, Spatial Variation and Compartmentalization of Trace Element in Brown Algae Cystoseira from Marine Protected Area of Crimea (Black Sea). Marine Pollution Bulletin, 97, 548554.

[16] Frontasyeva, M.V. (2011) Neutron Activation Analysis in Life Sciences. Physics of Particles and Nuclei, 42, 332-378. https://doi.org/10.1134/s1063779611020043

[17] Dmitriev, A.Y. and Pavlov, S.S. (2013) Automated Quantitative Determination of Elements in Samples by Neutron Activation Analysis at the IBR-2 at LNP JINR. Phisika elementarnikh chastits $i$ atomnogo yadra, 10, 58-64.

[18] Shams Eldin, N.G. and El-Sherif, Z.M. (2012) Nutritional Value of Some Algae from North-Western Mediterranean Coast of Egypt. Journal of Applied Phycology, 24, 613-262. https://doi.org/10.1007/s10811-012-9831-3

[19] Conti, M.E., Iacobucci, M. and Cecchetti, G. (2007) A Biomonitor Study: Trace Metals in Seagrass, Algae and Molluscs in a Marine Reference Ecosystem (Southern Tyrrhenian Sea). International Journal of Environment and Pollution, 29, 308-332. https://doi.org/10.1504/IJEP.2007.012808

[20] Malea, P. and Kevrkidis, T. (2014) Trace Element Patterns in Marine Macroalgae. Science of the Total Environment, 494-495, 144-157. https://doi.org/10.1016/j.scitotenv.2014.06.134

[21] Phillips, D.J.H. (1990) Arsenic in Aquatic Organisms: A Review, Emphasizing Chemical Speciation. Aquatic Toxicology, 16, 151-186. https://doi.org/10.1016/0166-445X(90)90036-O

[22] Babula, P., Adam, V., Opatrilova, R., Zehnalek, J., Havel, L. and Kizek, R. (2008) Uncommon Heavy Metals, Metalloids and Their Plant Toxicity: A Review. Environmental Chemistry Letters, 6, 189-213. https://doi.org/10.1007/s10311-008-0159-9

[23] Kabata-Pendias, A. and Pendias, H. (2001) Trace Elements in Soils and Plants. CRC Press, New York, 432 p. 
Submit or recommend next manuscript to SCIRP and we will provide best service for you:

Accepting pre-submission inquiries through Email, Facebook, LinkedIn, Twitter, etc. A wide selection of journals (inclusive of 9 subjects, more than 200 journals)

Providing 24-hour high-quality service

User-friendly online submission system

Fair and swift peer-review system

Efficient typesetting and proofreading procedure

Display of the result of downloads and visits, as well as the number of cited articles Maximum dissemination of your research work

Submit your manuscript at: http://papersubmission.scirp.org/

Or contact ajac@scirp.org 